\title{
The Moderating Effect of Self-Motivation on the Relationship between Parent's Socio-Economic Background and Children's Academic Performance at Nigerian Universities
}

\author{
Isidore Ekpe ${ }^{1}$, Mary Olufunmilayo Adelaiye ${ }^{2}$, Ernest Ikechukwu Adubasim ${ }^{3} \&$ Victor Chidiebere Adim $^{4}$ \\ ${ }^{1}$ Faculty of Entrepreneurship and Business, Universiti Malaysia Kelantan, Malaysia \\ ${ }^{2}$ Department of Business Administration and Management, Federal Polytechnic, Bauchi, Bauchi State, Nigeria \\ ${ }^{3}$ Management and Information Technology Programme, AbubakarTafawaBalewa University, Nigeria \\ ${ }^{4}$ Department of Management, University of Port-Harcourt, Nigeria \\ Correspondence: Isidore Ekpe, Faculty of Entrepreneurship and Business, Universiti Malaysia Kelantan, City \\ Campus, Locked Bag 36, Pengkalan Chepa, 16100 Kota Bharu, Kelantan, Malaysia. Tel: 60-19-983-0513. \\ E-mail: ekpe60@yahoo.com
}

\author{
Received: June 5, 2014 Accepted: July 8, 2014 Online Published: October 30, 2014 \\ doi:10.5539/ass.v10n21p73 URL: http://dx.doi.org/10.5539/ass.v10n21p73
}

\begin{abstract}
The purpose of this study is to examine the moderating effect of self-motivation on the relationship between parent's socio-economic backgrounds on their children's academic performance at Nigerian Universities, which has received little attention. Issues concerning University undergraduate youths have become a cause for concern among stakeholders in the project called 'education in Nigeria'. Such issues like expulsion from school due to examination malpractice or cultism, withdrawal due to poor academic performance and production of half-baked graduates have forced many concerned people to question the role of teachers as well as parent's socio-economic background. The paper adopted a survey methodology to solicit responses from 150 final year University students (2012/2013) of Business Faculties in the north, east and west regions of Nigeria; using stratified proportionate random sampling. After data cleaning, 130 data were analyzed using descriptive statistics and hierarchical regression. One of the results indicated that student's self-motivation (hard work) and rich parental socio-economic background are needed to achieve academic success; though self-motivation appears to be a more critical success factor. The paper recommended that the government and the authorities of Nigerian universities should intensify effort at counselling the students on the need to study hard in order to achieve academic success rather than relying on their parents' socio-economic background. This will improve teaching and learning in Nigerian Universities. The study is limited to University Business Faculties in Nigeria. Future studies can investigate other tertiary institutions in Nigeria.
\end{abstract}

Keywords: socio-economic background, self-motivation, academic performance

\section{Introduction}

Nigerian Universities offer courses that could be categorized into science, technology, engineering, social sciences and pure arts. These courses, theoretical and practical, are designed to relate the students to life experiences capable of achieving career success if they work hard and work by the rules. Various Examination Regulatory Agencies such as West African Examination Council, National Examination Council, and Joint Admission and Matriculation Board have decried the increasing cases of examination malpractices in Nigeria. Institutions of higher learning, such as Universities, have frequently shown serious concern about moral decadence among Nigerian undergraduate youths expressed in form of examination misconducts, cultism and sexual promiscuity, most of which led to expulsion or rustication from school and poor academic performance of such students. This can lead to negative impact on the economy and society at large.

Poor academic performance by University students, coupled with the present low employment level in Nigeria, can lead to serious social vices that can threaten the peace and security of the nation and divert the attention of the government from economic and infrastructural development. It can also lead to scarcity of manpower in all spheres of the economy, if not checked. Therefore, teachers and the learning environment should impact 
positively on the student's capability to learn. However, since the University is an umbrella that houses students from different parental background; their parents' social and economic background can have positive or negative effect on their academic performance. Studies have found that parent's socio-economic background has positive relationship with students' academic performance (Adekeyi, 2002; Hurlock, 2005; Ogunsola \& Adewale, 2012; Stones, 2004) as rich parents could provide financial, moral and social supports for their children. However, other studies (Udida et al., 2012) argued that children from rich families record poor academic performance in schools. Aside this, self-motivation is also a necessary variable that can impact on this relationship. That is, a student from a good parental socio-economic background may not achieve high academic performance if he/she is not determined to study hard. Also, a child from a poor parental socio-economic background can achieve high academic performance if he/she works hard. On this premise, the research is aimed at investigating the moderating influence of self-motivation on the relationship between parent's socio-economic background and their children's academic performance, particularly in Nigerian Universities. Numerous studies (Aremu, 2000; David, 2007; Farrant, 2004; Hurlock, 2005) have been done at the primary and secondary school levels but scant literature (Azhar et al., 2013; Eweniyi, 2005) exists that examined these variables at the university levels. Again, the moderating effect of self-motivation on these variables has received little empirical attention in literature as Abesha (2012) measured the moderating influence of self-efficacy on the relationship between socio-economic background and academic achievement in Ethiopia.

\section{Literature Review}

Social influence theory postulated that social ties, the influence of friends and family, role models and advisors have influence on behavior. Social networks provide access to information and resources necessary for success (Tata \& Prasad, 2008). Also Kuzilwa (2005), Shastri and Sinha (2010), concluded that social environment may hinder identification and exploitation of entrepreneurial opportunity. Other studies showed that perceived social environment had positive impact on students' entrepreneurial intentions in China (Yun \& Yuan-qiong, 2010). These studies indicated that social environment could influence student's behavior towards their academic excellence. Motivation theory, such as McGregor's Theory Y assumptions, holds that people exercise self-directed and self-control behavior in performing tasks. They are committed to set goals, accept responsibility, exercise ingenuity and creativity in solving problems. Porter and Lawler Motivation Model show that performance is a function of ability, the perception of the task required, and effort. Effort is influenced by the value of rewards and the perceived effort-reward probability. Performance is related to rewards and satisfaction. On this premise, it can be argued that parent's socio-economic background can only lead to student's academic performance if the student exercises self-motivation or self-determination to succeed by studying hard.

\subsection{Socio-Economic Background}

There are so many factors (school environment, learning facilities, teacher characteristics, and student's intelligent quotient) affecting student's academic performance. However, parent's social and economic background appears to be a major factor (Asikhia, 2010). Parents with higher status can provide their children with better financial support and home resources for individual learning (Schulz, 2005). Parent's skills and social networks can also be applied to the benefit of their children who are students. For instance, parents of a high class or middle class status in Nigeria will want their children to attend high-fees institutions such as foreign or private Universities with stable academic calendar and good infrastructural facilities conducive for learning. Such students will likely achieve higher academic performance than their colleagues in local or public Universities.

Parents with fewer children have the economic or financial capability to acquire a better education for their children. Parent's social status in terms of educational attainment and occupation also play significant role in children's academic performance (Osunloye, 2008). The studies of Blair et al. (2008) indicated that good social relationship with parents at home (strong social attachment), peers and adults at school produced better behavior and quest for excellence or distinction which led to high academic achievement. However, Asikhia (2010) argued that social and economic background should be lumped together (socio-economic) because they are related.

It is widely reported that parent's socio-economic background affects student's school achievement (Adekeyi, 2002; David, 2007; Ezewu, 2003; Farrant, 2004; Hurlock, 2005; Ogunsola \& Adewale, 2012; Stones, 2004) as rich parents could afford high-fee schools, textbooks, extra lessons, good feeding and upkeep money at school and domestic servants at home to relieve the students of house chores; while students from poor homes take up part-time jobs to supplement their income while in school. According to Ipaye (1996), many male students on 
campus from poor economic background took to part-time jobs and entrepreneurship to support themselves and even their younger ones, while the female ones took to prostitution, which acts took much of their time and were left with less time for studies. Such students neither have access to extra learning opportunities like extra-moral lessons and road-side computer training, nor can they afford instructional materials in their chosen careers, and these led to poor academic performance. However, other studies (Udida et al. (2012) argued that children from rich families record poor academic performance in schools. We, therefore, hypothesized that:

\section{H1: Parent's socio-economic background is positively related to their children's academic performance}

\subsection{Self-motivation}

Weihrich et al. (2008) refers to motivation as a general term applying to the entire class of drives, desires, needs, wishes and similar forces. Therefore, one can be motivated by personal drive or desire to achieve success. Though it has been posited by previous literature (Meyer et al. 1993; Ogunsola \& Adewale, 2012; Osunloye, 2008; Schulz, 2005) that parent's socio-economic background influences children' academic performance in school; however, self-motivation can aid or hamper these variables' relationship because a student from a good parental socio-economic background may not achieve high academic performance if he/she is not determined to work hard. This is in line with human development and welfare issues which places the 'individual' at the centre of employees' motivation. Also, since Udida et al. (2012) discovered that students from rich homes perform poorly academically, then these studies have shown inconsistent results, and this calls for a moderator (Baron \& Kenny, 1986). We, therefore, hypothesize that:

H2: Self-motivation moderates the relationship between parent's socio-economic background and children's academic performance.

\section{Methodology}

\subsection{Survey Procedures}

A quantitative research method (survey) was employed to collect data from final year undergraduate students of three University' Business Faculties in the North, East and West regions of Nigeria from 2012 to 2013; using stratified proportionate random sampling. The population was chosen because Universities in Nigeria offer similar courses. From a total population of 563 final year students from the three university business faculties, a total sample size of 275 students was used; determined by Israel (1992) based on Yamane's (1967) formula for finite population: $\mathrm{n}=\mathrm{N} / 1+\mathrm{N}(\mathrm{e})^{2}$. From the questionnaires returned, 150 questionnaires were usable. However, after data cleaning, data for 130 students were used for the analysis. Data were analyzed using descriptive statistics and hierarchical regression.

\subsection{Measures}

Parent's socio-economic background was measured in terms of parent's educational attainment and occupation in line with Osunloye (2008) and Meyer et al. (1993). Self-motivation was measured in terms of determination to succeed and academic performance was measured in terms of study outcome. The measures were adapted from same sources. All the measures were tapped on a 4-point scale.

The conceptual framework for this study is shown in Figure 1 below:

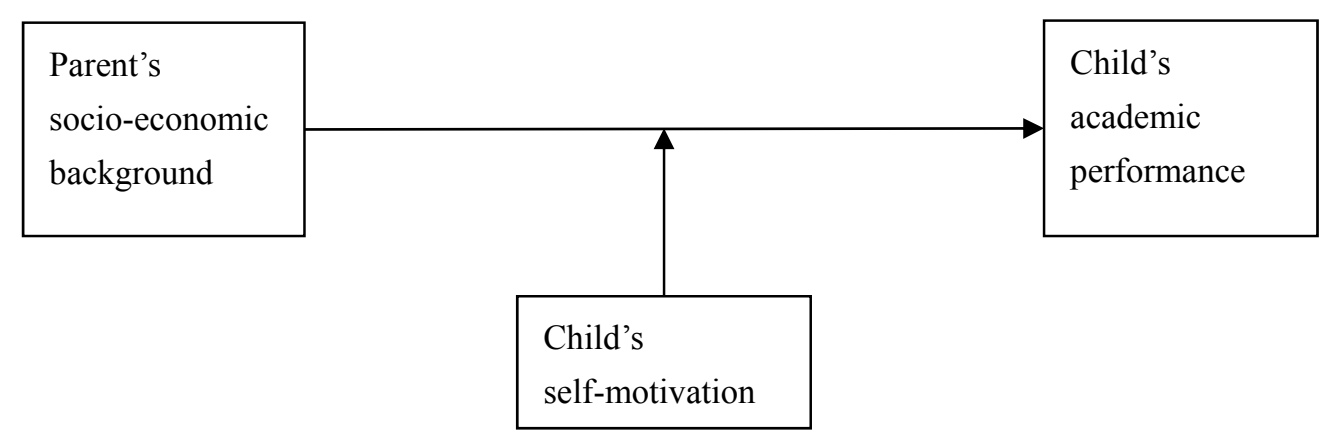

Figure 1. Conceptual model 
The moderator-interaction effects were determined in line with the procedure suggested by Baron and Kenny (1986). A moderator-interaction effect would occur if a relation is substantially reduced instead of being reversed (Baron \& Kenny, 1986). Again, a moderator hypothesis is supported if the interaction or the product of a predictor variable and the moderator is significant when the predictor and the moderator were being controlled (Baron \& Kenny, 1986).

\section{Results}

\subsection{Data Cleaning}

The data used were free from errors. For instance, outliers were detected by comparing the Mahalanobis distance $\left(\mathrm{D}^{2}\right)$ or chi-square value of each respondent with the critical or table chi-square value, using the number of predictor variables as the degrees of freedom, at $p<0.001$ (Hair et al., 2010). Extreme observations in a sufficient number of variables in multivariate and univariate detections were deleted (Hair et al., 2010). Normality was handled through skewness and kurtosis. Observations with Z-score above or below the critical value of 1.96, at $\mathrm{p}=0.05$ were deleted (Hair et al., 2010). Linearity was detected through Pearson correlation matrix and all predictors correlated with the criterion variable. The output of the hierarchical regression analysis indicated that the error term (as indicated by Durbin Watson statistics) were all within the recommended range of $1.50-2.50$. There was no case of multicollinearity as the collinearity statistics of the regression output indicated Tolerance $>0.10$, Variance Inflationary Factor $<10$ and Condition index $<30$ in most cases (Hair et al., 2010). Homoscedasticity (equality of variance) was verified through an examination of the residuals of the regression output which showed no clear relationship between the residual and the predicted values (Coakes\& Steed, 2003).

\subsection{Goodness of Measures}

The principal component analysis for the predictor variables revealed the presence of one component with eigenvalues greater than one, using Varimax with Kaiser's normalization rotation method. This one component factors was renamed poor socio-economic background (missing school to help parent sell). The naming was done according to the items with the highest factor loadings in the component. The one component explained a total variance of $64.27 \%$. Communalities were above 0.6 for most variables, anti-image (MSA) was above 0.5 for each item and Barlett's test of sphericity (sig.) was 0.000 which was $<0.05$. Kaiser-Meyer-Olkin' measure of sampling adequacy was 0.711 and factor loadings were above 0.5 as suggested by Hair et al. (2010). The moderator converged into one component renamed child's self-motivation (doing all school homework and assignments) with a total variance explained as $55.30 \%$. Communalities were above 0.6 for most items, MSA was also above 0.5 and Barlett's test of sphericity (sig.) was 0.000 . Factor loadings were above 0.5 and KMO was 0.717 . The criterion variable converged into one component renamed child's academic performance (if parent support me and I work hard, I have success); with a total variance explained of $63.93 \%$. Communalities were above 0.6 for most items, MSA was above 0.5 and Barlett's test of sphericity (sig.) was 0.000 . Factor loadings were above 0.5 and $\mathrm{KMO}$ was 0.701 .

After the principal component factor analysis (EFA), the data were standardized by finding the mean of items of each factor or construct which then became the variables for subsequent analyses such as 'reliability'. However, for hierarchical regression, the variables were centralized to avoid high multicollinearity (Aiken \& West, 1991). Prior to hierarchical regression, the independent variables were multiplied with the moderator to get the product of interaction terms that were entered into specific levels of the hierarchical regression analysis.

Reliability test was performed on the factors after the exploratory factor analysis. Poor socio-economic background had Cronbach's alpha of 0.68. Alpha for child's self-motivation (hard work) was 0.72. Alpha for child's academic performance was 0.73 . This is shown in Table 1 below:

Table 1. Descriptive analysis of the variables (mean and standard deviation) and reliability

\begin{tabular}{lccccc}
\hline \multicolumn{1}{c}{ Variable } & Mean & $\begin{array}{c}\text { Std. } \\
\text { Deviation }\end{array}$ & $\begin{array}{c}\text { Cronbach' alpha } \\
\text { coefficient }\end{array}$ & $\begin{array}{c}\text { No. of Items } \\
\text { measured after EFA }\end{array}$ & $\begin{array}{c}\text { Sample size (N) } \\
\text { after EFA }\end{array}$ \\
\hline $\begin{array}{l}\text { Parent' poor socio-economic } \\
\text { background (PPSEB) }\end{array}$ & 1.56 & 0.57 & 0.68 & 4 & 130 \\
$\begin{array}{l}\text { Child's self-motivation/hard work } \\
\text { (CSM) }\end{array}$ & 3.36 & 0.56 & 0.72 & 4 & 130 \\
$\begin{array}{l}\text { Child' academic performance } \\
\text { (CAP) }\end{array}$ & 3.55 & 0.50 & 0.73 & 4 & 130 \\
\hline
\end{tabular}


Table 1 above provided a summary of the descriptive statistics of the variables. It indicated that the predictor variable (poor parental socio-economic background) had a lower mean of 1.56 and standard deviation of 0.57 , which showed that poor parental socio-economic background, could not lead to child's academic success. The moderated variable (child's self-motivation) had a higher mean value (3.36) and standard deviation (0.56) than the predictor variable. This proved that poor socio-economic background could not hinder a child's academic success if he works hard. That is, the child's personal effort is more critical to achieving academic success than his/her parent's socio-economic background. Therefore, for parent's socio-economic background to have any positive effect on the child's academic performance; the child's self motivation (hard work) is the critical factor needed.

\subsection{Testing Hypotheses}

In Table 2 below, Beta 1 (step 1) showed the direct influence of parent's poor socio-economic background on child's academic performance. The R square was 0.002 . In other words, this independent variable explained only $0.2 \%$ of the variance in child's academic performance $(\mathrm{R}$ square change $=0.002)$. The overall regression model was insignificant $(\mathrm{Sig} . \mathrm{F}$ change $=0.625, \mathrm{R}$ square $=0.002, \mathrm{~F}$ change $=0.240$ ). From the individual coefficients, parent' poor socio-economic background (beta $=0.043$ ) was also insignificant. This indicated that parent's poor socio-economic background was not a critical factor to child's academic performance. In beta 2 (step 2), when the moderator was entered, the $\mathrm{R}$ square was 0.202 . This showed that total variance explained by the model as a whole became $20.2 \%$ ( $\mathrm{R}$ square $=0.202, \mathrm{~F}$ change $=31.906, \mathrm{p}<0.001)$. The additional variables explained an additional $20.2 \%$ of the variance in child's academic performance, after controlling parent's poor socio-economic background $(\mathrm{R}$ square change $=0.200)$. The overall model was significant $(\mathrm{Sig} . \mathrm{F}$ change $=$ $0.000, \mathrm{p}<0.001$ ). This proved that a child' self-motivation aids academic success. In beta 3 (step 3 ), when the interaction was performed, then $\mathrm{R}$ square became 0.204 . This showed the total variance explained by the model as a whole was $20.4 \%$. The interaction effect was noticed by the increase in $\mathrm{R}$ square value by $2 \%$ ( $\mathrm{R}$ square change $=0.002)$ which explained an additional $2 \%$ of the variance in academic performance (R square $=0.204$, $\mathrm{F}$ change $=0.34)$. The overall model was insignificant $(\mathrm{Sig} . \mathrm{F}$ change $=0.561)$. This proved that poor parental socio-economic background cannot hinder a highly self-motivated child from achieving academic success.

Table 2. Results of hierarchical regression on child' academic performance

\begin{tabular}{llll}
\hline Variables & Beta 1(Step 1) & Beta 2(Step 2) & Beta 3(Step 3) \\
\hline $\begin{array}{l}\text { Independent Variable: } \\
\text { PPSEB }\end{array}$ & 0.43 & $0.132^{*}$ & 0.383 \\
Moderator: & & & \\
CSM & & $0.456^{* * * *}$ & $0.576^{*}$ \\
Interaction Term: & & & -0.260 \\
PSEB*CSM & 0.002 & 0.202 & 0.204 \\
R Square & -0.006 & 0.190 & 0.185 \\
Adjusted R Square & 0.002 & 0.200 & 0.002 \\
R Square Change & 0.240 & 31.906 & 0.34 \\
F Value & 0.625 & $0.000^{* * * *}$ & 0.561 \\
Sig. F Change & &
\end{tabular}

Note: $* * * * \mathrm{p}<.001 ; * * * \mathrm{p}<.01 ; * * \mathrm{p}<.05 ;{ }^{*} \mathrm{p}<.10$

$\mathrm{DV}=$ Child' academic performance, $\mathrm{PPSEB}=$ Parent's poor socio-economic background, CSM $=$ Child's self-motivation.

H1: Parent's socio-economic background is positively related to their children's academic performance. From the regression result in Table 2 (step 1), it was discovered that parent's poor socio-economic background had insignificant relationship with child' academic performance. Thus, hypothesis 1 was supported.

H2: Self-motivation moderates the relationship between parent's poor socio-economic background and children's academic performance. As shown in Table 2 (step 3), the interaction effect was insignificant, and in Table 2 (step 2), child' self-motivation had significant influence on child' academic performance (beta $=0.456, \mathrm{p}$ $<0.001)$. Thus, hypothesis 2 was supported. 


\section{Discussion}

Previous studies posited that parent's socio-economic background positively affects student's school achievement as rich parents could afford high-fee schools, textbooks, extra lessons, good feeding and upkeep money at school and domestic servants at home to relieve the students of house chores; while students from poor homes take up part-time jobs to supplement their income while in school (Azhar et al. 2013; Blair et al., 2008; David, 2007; Osunloye, 2008). On the other hand, Udida et al. (2012) found that children from rich homes record poor academic performance in schools. Generally, this study supported previous studies in the field (Ekpe et al., 2011; Eweniyi, 2005; Azhar et al., 2013). Specifically, the study has made a striking and novel discovery that student's self-motivation (hard work) and rich parental socio-economic background are needed to achieve academic success; though self-motivation appears to be a more critical success factor. The government and the authorities of Nigerian universities should, therefore, intensify effort at counselling the students on the need to study hard in order to achieve academic success rather than relying on their parental socio-economic background.

\section{References}

Abesha, A. G. (2012). Effect of parental styles, academic self-efficacy and achievement motivation on academic achievement of university students in Ethiopia. Unpublished Thesis submitted to School of Psychology, Faculty of Computing, Health and Science, Edith Cowan University, Perth, Western Australia.

Adekeyi, A. (2002). Teaching social studies in Nigeria colleges. Ile-Ife, University Press.

Aremu, A. O. (2000). Impact of home, school and government on primary school pupils' academic performance. Journal of the Exceptional Child, 5(1), 106-110.

Asikhia, O. A. (2010). Students' and Teachers' perception of the causes of poor academic performance in OgunState secondary schools (Nigeria): Implications for counselling for national development. European Journal of Social Sciences, 13(2), 229-249.

Azhar, M., Nadeem, S., Nar, F., Perveen, F., \& Sameen, A. (2013). Impact of parental education and socio-economic status on academic achievement of university students. International Journal of Academic Research and Reflection, 1(3), 25-33.

Baron, R. M., \& Kenny, D. A. (1986). The moderator-mediator variable distinction in social psychologyresearch: Conceptual, strategic, and statistical considerations. Journal of Personality and Social Psychology, 51(6), 1173-1182. http://dx.doi.org/10.1037//0022-3514.51.6.1173

Blair, K., Shaywitz, J., Smith, B. W., Rhodes, R., Geraci, M. R. N., \& Jones, M. (2008). Response to emotional expressions in generalized social phobia and generalized anxiety disorders: Evidence for separate disorders. American Journal of Psychiatry, 165, 1193-1202.

David, W. I. (2007). Educational Psychology. New Jersey: Prentice-Hall Inc.http://dx.doi.org/10.4324/9780203 806197.

Ekpe, I., Mat, N. \& Razak, C. R. (2011). Attributes, environment factors and women entrepreneurial activity: A literature review. Asian Social Science, 7(9), 124-130. http://dx.doi.org/10.5539/ass.v7n9p124

Eweniyi, G. D. (2005). The impact of family structure on university students' academic performance. Ilorin Journal of Education, 21, 19-25.

Ezewu, E. (2003). Influence of family background on the academic achievements of pupils. Sociology ofeducation. Lagos: Longman Group Limited.

Farrant, J. S. (2004). Principles and practice of education. London: Longman.

Hurlock, E. B. (2005). Child development. New York: McGraw-Hill Book Company Inc. http://dx.doi.org/10.1097/00000446-195103000-00070

Ipaye, A. (1996). Future Trends in special education. A keynote address presented at the CENDP/UNESAO sponsored programme on current researches in special education. Federal College of Education(special) Oyo, Nigeria

Israel, G. D. (1992). Determining sample size. Retrieved May 5, 2014, from http://edis.ifas.ufl.edu/ pdffiles/PD/PD00600.pdf

Kuzilwa, J. (2005). The role of credit for small business success: A study of the National Entrepreneurship Development Fund in Tanzania. The Journal of Entrepreneurship, 14(2), 131-161. http://dx.doi.org/ 


\section{$10.1177 / 097135570501400204$}

Meyer, J. P., Allen, N. J., \& Smith, C. A. (1993). Commitment to organizations and occupations: Extension and test of a three-component conception. Journal of Applied Psychology, 78, 538-551.

Ogunsola, F., \& Adewale, A. M. (2012).The effect of parental socio-economic status on academic performance of students in selected schools in Edu L.G.A of Kwara State of Nigeria. International Journal of Academic Research and Social Sciences, 2(7), 230-239.

Osunloye, A. (2008). Family background and student academic performance. Retrieved February 23, 2014 from http://socyberty.com/edu/family-background-and-student academic performance/

Schulz, W. (2005). Measuring the socio-economic background of students and its effect on achievement. A paper presented at the Annual meeting of the American Educational Research Association (7-11 April2005). San Francisco.

Shastri, R. K.,\& Sinha, A. (2010). The socio-cultural and economic effect on the development of women entrepreneurs (with special reference to India). Asian Journal of Business Management, 2(2), 30-34.

Stones, E. (2004). An introduction to educational psychology. Ibadan: Spectrum Books Limited.

Tata, J., \& Prasad, S. (2008). Social capital, collaborative exchange and microenterprise performance: The role of gender. International Journal of Entrepreneurship and Small Business, 5(3/4), 373-385. http://dx.doi.org/10.1504/IJESB.2008.017310

Udida, L. A., Ukwayi, J. K., \& Ogodo, F. A. (2012). Parental socio-economic background as a determinant of student's academic performance in selected public secondary schools in Calabar Municipal L.G.A, Cross River State, Nigeria. Journal of Education and Practice (online), 3(16), 129-134.

Weirich, H., Cannice, M. V., \& Koontz, H. (2008). Management: A global andentrepreneurial perspective (12th ed.). New Delhi, McGraw-Hill Co.

Yun, C., \& Yuan-qiong. (2010). The impact of perceived social environment on students' entrepreneurial intentions: A Chinese perspective. A paper presented at the International Conference, 7-9 November2010 (pp. 1-4). Henan: E-Product, E-Service and E-Entertainment (ICEEE).

\section{Copyrights}

Copyright for this article is retained by the author(s), with first publication rights granted to the journal.

This is an open-access article distributed under the terms and conditions of the Creative Commons Attribution license (http://creativecommons.org/licenses/by/3.0/). 